\title{
The binding of actinocin derivative with DNA fragments (Monte Carlo simulation)
}

\author{
A.V. Shestopalova \\ Usikov Institute of Radio Physics and Electronics \\ 12, Proskura st., Kharkov, 61085, Ukraine \\ shestop@ire..kharkov.ua
}

\begin{abstract}
The computer simulations of the interaction of DNA fragments and actinocin derivative (ActII) with ligand-target ratio 1:1 and 2:1 were carried out by a Monte Carlo method taking into account water environment. Low-energy molecular structures corresponding to the most probable models of two types of complexes - binding of ActII in minor groove and intercalation of ActII into GC-site with different complex stehiometry were obtained The energetic and structural parameters of the complex formation were calculated. The stability of investigated complexes was conditioned by Van der Waals and electrostatic interactions as well as by the interaction with a solvent. The water molecules contribute to the stabilization of complexes due to the formation of water bridges between donor-acceptor groups of DNA fragments and ligands. Possible sizes of ActII binding sites in the minor groove were determined. They equaled 3-4 b. p. per the ligand molecule. The sizes of binding sites of intercalating ActII molecules into GC-site are obviously bigger than 4 b. p. per the ligand molecule. The results obtained are in agreement with the experimental data.
\end{abstract}

Keywords: DNA fragments, actinocin derivative, complexation, Monte Carlo method, size of binding site, hydration.

Introduction. Studying the processes of molecular recognition and complex formation of nucleic acids (NA) with biologically active substances (BAS) it is of great importance to determine the following: i) localization of possible binding sites and their measurements; ii) the structure of sites and energetic parameters of binding; iii) the most probable molecular models of complexes.

One of the most widely spread methods of localization of binding sites of ligands with NA are the methods connected with spectrophotometrical investigations of NA and BAS in UV- and visible regions. In order to perform a detailed analysis of types and structures of the complexes formed, the titration

(C) A.V. Shestopalova., 2007 curves (concentration dependencies of mixture absorption spectra) are built, which reflect the spectral changes in each system under investigation. These concentration dependencies for NA-BAS may be used for determining the constants and localizing the binding sites $[1,2]$.

Many ligands capable of interacting with NA form two main types of complexes: binding in the grooves of twin NA helix and intercalation or incorporation of planar heterocyclic chromophore between the surfaces of neighboring NA nucleotide pairs. The values of binding sites at intercalation are basically low. Intercalating ligands may be divided by $1-4$ basic pairs (b.p.) [3]. Binding ligands in DNA grooves, binding sites measurements are higher than those at 
intercalation and equal 3-6 b.p. or more depending on the ligand structure [4].

Experimental investigation on molecular mechanisms of complex formation of analogue anticancer antibiotic actinomycin D (actinocile-bis(2-dimethylaminopropyl-amine) - ActII with natural DNA revealed the possibility of obtaining two types of complexes $[5,6]$. The first one can be viewed as external binding of ligand in minor or major DNA grooves, and the second one can be considered to be intercalation.

Using spectrophotometry investigation of complex formation ActII with three DNA samples (different in AT/GC-content) and subsequent analysis of the results the measurements of the binding site for the first type of the complex (groove binding) were shown to be the same for all investigated systems, equal to $\sim 3$ b.p. per ActII molecule, and depend slightly on GC-pair contents [7].

Optimal values of the binding sites for the second type of complexes increase depending on GC-pairs contents decrease, whereas the corresponding binding constants do not change significantly. Authors make the supposition that these data testify in favor of GC-specificity of binding ActII and possible intercalation between two neighboring GC-pairs. Analysis of the results revealed that the size of the binding site for this type of complex is in inverse proportion to the value of the possibility of close location of two GC-pairs and equals 3.2 for $\mathrm{DNA}_{M . l y s}(\mathrm{GC} \sim 76 \%), 6$ for $\mathrm{DNA}_{\text {thym. }}(\mathrm{GC} \sim 42 \%$ ), and 12 for $\mathrm{DNA}_{\text {Cl.perf. }}(\mathrm{GC} \sim 28 \%)$. Therefore, two types of complexes formed at different sites and different in the size of the binding site are present in ActII-DNA systems [7].

Detailed representation of possible ActII-DNA structural complexes may be obtained using computer modeling accepting the data of X-ray structural analysis of complex DNA fragments and ligands and the data on spectrophotometry for particular ActII-DNA system as the obligatory data.

Current work presents the data of computer modeling of ActII complexes with different DNA fragments according to two types of binding. The main tasks of the investigation were to model the complexes (ligand-NA ratio $1: 1$ and 2:1) and to assess the binding sites for two types of complexes. The possibility of stable complex formation between Act II and several DNA fragments for two different types of binding 1:1 was shown by Monte Carlo method and methods of molecular dynamics [8-10]. Computer modeling allowed obtaining structures corresponding to energy minimum (or the most probable equilibrium state of ActII-DNA fragment) and evaluating the water environment in the process of complex formation.

Materials and Methods. To select optimal molecular models of hydrated complexes ActII and DNA using the Monte Carlo method, computer modeling of the interaction of two different DNA fragments and ActII taking into account water environment has been performed. Energy and structure characteristics were calculated and instantaneous configurations, necessary for building the molecular models and water environment of the investigated complexes, were obtained.

The application of the Monte Carlo method for investigating the hydration of small molecules, NA fragments, and their components is presented in detail in $[11,12]$. This investigation presents the calculations in canonical $(N, V, T)$ ensemble in the frames of Metropolis algorithm [13]. In each of these systems the number of water molecules was 800 , system temperature $-298 \mathrm{~K}$.

To calculate interaction energies values, semiempirical atom-atom potential functions suggested by Poltev et al. have been used [14, 15]. Total interaction energy of the system is presented as the sum of water-water, water-DNA, water-ligand, DNA-ligand, and ligand-ligand interaction energies. Water-water interaction energy is approximated by atom-atom potential function of 1-6-exp type [14]:

$$
\mathrm{U}_{i j}=\Sigma\left[\mathrm{C}_{i j} \mathrm{q}_{i} \mathrm{q}_{j} / \mathrm{r}_{i j}-\mathrm{A}_{i j} \mathrm{r}_{i j}^{-6}+\mathrm{B}_{i j} \exp \left(-\mathrm{D}_{i j} \mathrm{r}_{i j}\right)\right] \text { (1) }
$$

The parameters are selected in a specific way in order to reproduce the energies of hexagonal crystalline lattice of ice and force coefficients of ice hydrogen bonds $(\mathrm{H})$. The model of water molecule and the selected type of potential function reproduce satisfactorily thermodynamic and structural parameters of liquid water and water solutions obtained experimentally. 


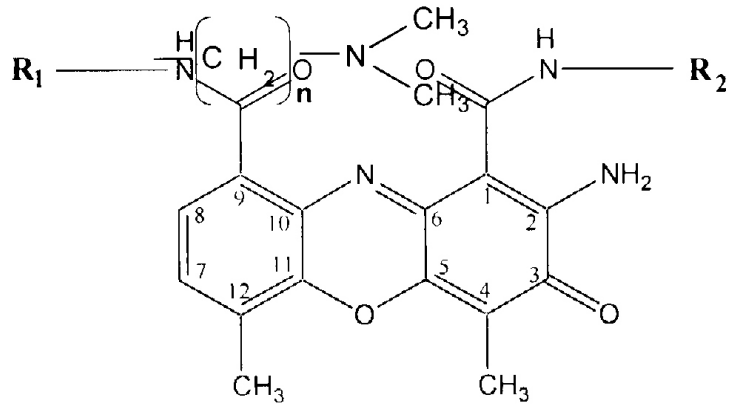

Energy values of water-DNA, water-ligand, and ligand-ligand are approximated by atom-atom potential function of 1-6-12 type [14, 15]:

$$
\mathrm{U}_{i j}=\Sigma\left[\mathrm{C}_{i j} \mathrm{q}_{i} \mathrm{q}_{j} / \mathrm{r}_{i j}+\mathrm{A}_{i j} \mathrm{r}_{i j}^{-12}-\mathrm{B}_{i j} \mathrm{r}_{i j}^{-6}\right]
$$

The parameters of potential functions are selected in a specific way in order to reproduce the lengths of $\mathrm{H}$-bonds between the molecules of water and NA components, as well as experimentally determined positions of water molecules in crystalline hydrates of bases, nucleosides, nucleotides and some ligands.

Cluster approximation (during which the system was placed in the sphere with firm reflecting walls in such a way that the solution center of masses matched the sphere center) was used as limiting conditions [16]. Initially, only the water molecules with the most advantageous structure obtained by preliminary modeling of cluster containing 800 water molecules were placed in the center of the sphere. The radius of the sphere was selected to be equal to the radius of the sphere, obtained for such water structure, i.e. $24.5 \AA$. Later on the radius of the sphere was increased for the value necessary for water molecules pressed out of water "drop" during the placement of complex into the center of the sphere. The radius used in current work was increased up to $40.5 \AA$. The number of elementary configurations performed in order to achieve the equilibrium state of water cluster equaled (4-6) $\mathrm{C} 10^{6}$, $(4-6) \mathrm{C} 10^{6}$ of elementary configurations were performed additionally to calculate energy characteristics.

Energy and structural characteristics of systems containing ActII, DNA fragments, and their complexes in aqueous clusters were calculated in a similar way.

$$
\mathbf{R}_{\mathbf{1}}=\mathbf{R}_{\mathbf{2}}=\mathbf{n}
$$

Act II: $\mathbf{n}=2$
Fig.1 Structural formula of actinocile-bis(2-dimethylaminopropyl-ami ne) - ActII molecule
Initially, to achieve equilibrium state $32 \mathrm{C} 10^{6}$ of elementary tests were performed, then thermodynamic parameters of the system on the equilibrated region were calculated, for this purpose $32 \mathrm{C} 10^{6}$ of elementary tests were generated. Statistical error occurring due to the limited number of configurations was estimated by the method of control functions. At that the whole set of elementary configurations was divided by final number of intervals. Thermodynamic values were calculated for each interval (in this work this is the total system energy) while standard deviation did not exceed \pm 0.005 .

The values of charges on the NA fragment atoms were accepted as in [17]. Coordinates and charge values of ActII atoms (Fig.1) were obtained by $a b$ initio HF/3-21G(p) method using GAMESS software (GAMESS QC Software (US)) [18] adapted for Windows NT (Granovsky A. A., http://www.classic.chem.msu.su/gran/gamess/index.ht $\mathrm{ml})$.

NA fragments in the solution at physiological conditions were negatively charged due to total ionization of phosphate groups. Neutralization of the charge on phosphate groups was performed by means of counterions, i.e. $\mathrm{Na}^{+}$ions. Counterions in the calculations presented, necessary for neutralization of phosphate groups, are not taken into account explicitly, however the charges of phosphate groups are calculated in regards of preserving the condition of electroneutrality. Such approximation is used in conformational analysis of NA and their fragments [17] and in the studies on hydration of di- and oligonucleotides by the Monte Carlo method [19].

Results and Discussion. The study considers two possible variants of complex formation formed by 
actinocine derivatives in accordance with the data presented in [5-8]. These are the incorporation of ligand molecules into the minor groove of the double helix and intercalation of ligands between GC-pairs surfaces of the double strand DNA. Initial configurations of complex coordinates obtained by the method of X-ray analysis were the following i) DNA fragment 5 -d(CCAACGTTGG) $)_{2}$ and two antramycin molecules which form the complex by external linkage in minor groove of the DNA (NDB index: GDJB29, PDB index: 274D) [20] and ii) DNA fragment with two molecules

N-cyanomethyl-N-(2-methoxyethyl)-daunomycin, intercalated in GC-sites of 5 -d(CGATCG) 2 DNA fragment (NDB index: dd0017-NDB, PDB index 482D) [21]. Configuration of NA fragments remained stable in the course of calculations. The position of ligands in complexes changed in frames of Metropolis algorithm. This procedure is similar to firm docking procedure taking into account the molecules of solvent.

Studying possible sizes of ActII binding sites with DNA fragments we have considered binding of one ligand molecule in the possible binding site. For this purpose, ActII molecule was placed in the same position with antramycin molecule (minor groove of 5 -d(CCAACGTTGG) $)_{2}$ ) or chromophore of one of $\mathrm{N}$-cyanomethyl-N-(2-methoxyethyl)-daunomycin molecules (intercalation into one of GC-sites of 5 -d(CGATCG $\left.)_{2}\right)$. This procedure was performed for each of possible positions of ligands of both complexes with subsequent geometrical optimization of complexes first in the borders of Metropolis algorithm and then the modeling of the optimized structure in water cluster was performed.

Studying ActII-DNA complexes (2:1) both molecules were placed into the position of two ligand molecules in crystallographic complexes with DNA fragments. Later on, the complexes were optimized geometrically in vacuum approximation and the complex was placed into the cluster of 800 water molecules.

The Table presents the results of energy and structural characteristics calculations of the systems under investigation.

The analysis of the results obtained reveals that the formation of all complexes is energetically profitable.
The mentioned fact allows making the conclusion on the possibility of DNA complex formation with both one and two ActII molecules located in binding sites of the selected size. It is worth mentioning that studying the binding of methylene blue in the minor DNA groove using molecular docking and Monte Carlo method in order to obtain low-energy conformation of complexes, ligand-DNA fragment interaction energies were determined to be from -200.1 to $-177.8 \mathrm{kcal} / \mathrm{mol}$ [22]. These results are in good correlation with the modeling of interaction ActII-DNA fragments energies values ( ${ }^{+} \mathrm{U}_{\text {DNA-ActII }}$, Table) recalculating it per 1 ligand molecule. This correlation testifies in favor of adequacy of the method used and the modeling parameters selected in order to investigate the systems DNA fragment-ActII.

Having analyzed the set of instantaneous configurations of complexes obtained on the equilibrated area of modeling, the sizes of binding sites can be estimated. During binding in the minor groove two ActII molecules occupy three base pairs and are separated by three more pairs (Fig.2, $a$ ). While the interaction energies of both ligand molecules with the fragment differ insignificantly $\left({ }^{+} \mathrm{U}_{\text {DNA-ActII }},{ }^{+} \mathrm{U}_{\text {DNA-ActII }}\right.$, Table), however, the interaction energies between ActII molecules $\left(\mathrm{U}_{\text {ActII-ActII }}\right.$, Table) reveal the repulsion of ActII molecules.

Similar conclusions for the complex with intercalated ligands can be made. The interaction energy between ActII molecules $\left(\mathrm{U}_{\text {ActI-ActII }}\right.$, Table) for this type of the complex is significantly higher, i.e. the repulsion of ligands is higher. Obviously, the size of the binding sites, used in modeling are smaller than those necessary for diminishing the repulsion between positively charged side chains of ligands. Molecules intercalated into GC-sites were proven to be separated by 2 b.p. and two more b.p. form the borders of binding sites, i.e. the size of the binding site for this type of the complex can set to be 4 b.p. (Fig.3, a). According to the experimental data [7], the value of the binding site for ActII at intercalation varies in the borders from 6 to 12 b.p. for high GC content DNA. High positive values of $\mathrm{U}_{\text {Actl-ActI }}$ energies may testify in favor of noncooperativity of ActII-DNA binding for the intercalation complex. The cooperativity factor (or any parameter characterizing ligand-ligand interaction) was 
Table 1 Energy and structural characteristics of systems, containing different complexes of DNA fragments and ligand (ActII) in aqueous cluster

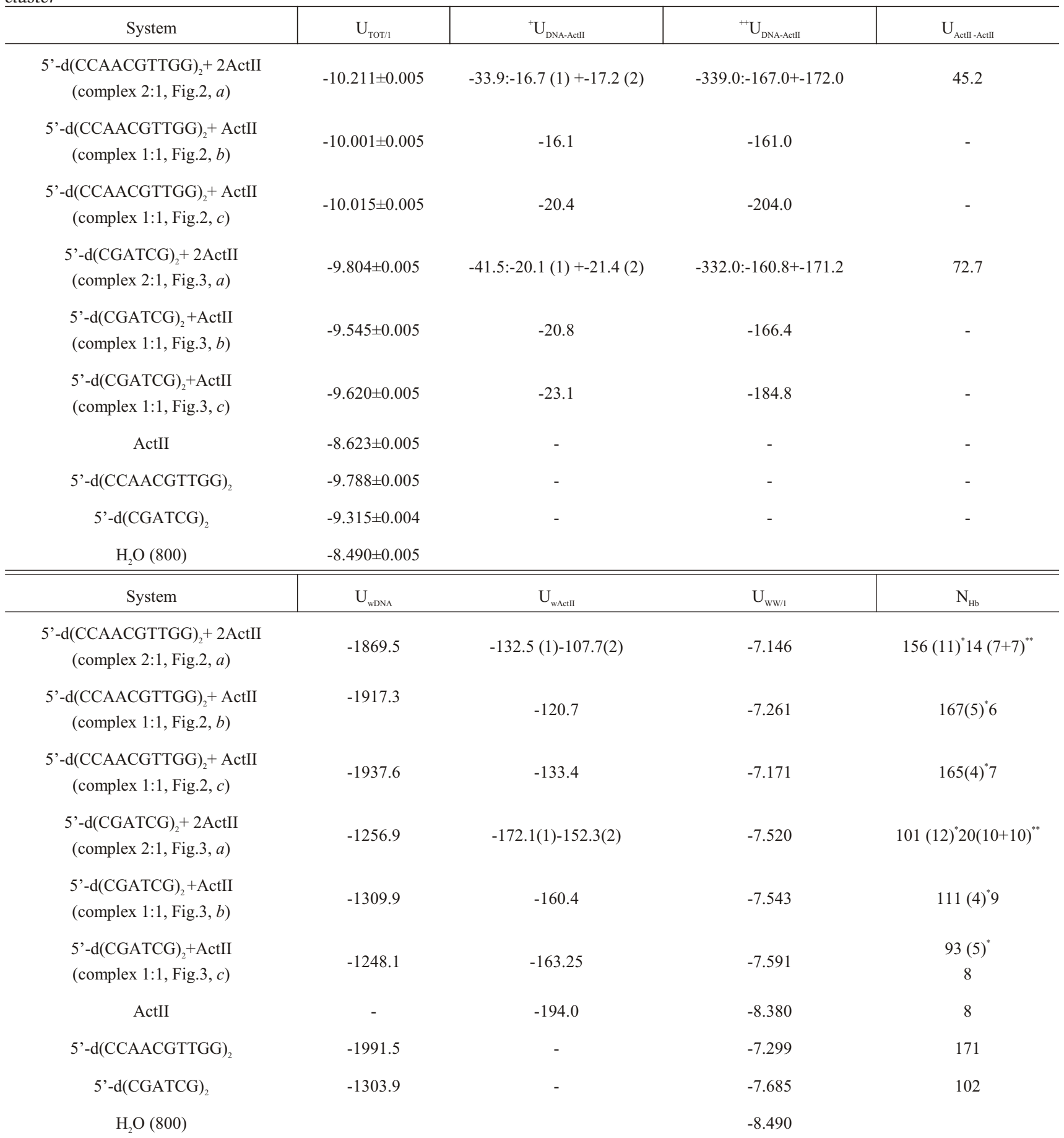

NB: the following signs were used in the Table: $U_{\text {TOT/1 }}-$ complete interaction energies in systems (per water molecule); $U_{\text {ww/1 }}-$ water-water interaction energies (per water molecule); interaction energies: $U_{\text {wDNA }}-$ DNA fragment - water and $U_{\text {wActII }}-$ ActII-water (per system); $U_{\text {DNA-ActII }}-$ DNA-ActII fragment (per base pair); $\mathrm{U}_{\text {Actl-ActII }}-$ ActII-ActII fragment (per molecule of ligand); $\mathrm{N}_{\mathrm{Hb}}$ - number of water molecules forming H-bonds with DNA or ActII fragments; ${ }^{+}$- per base pair; ${ }^{+}$- per molecule of ligand; * number of water molecules occupying bridge position between groups of DNA fragment and ActII; ** number of water molecules forming hydrogen bonds with each ActII molecule. 


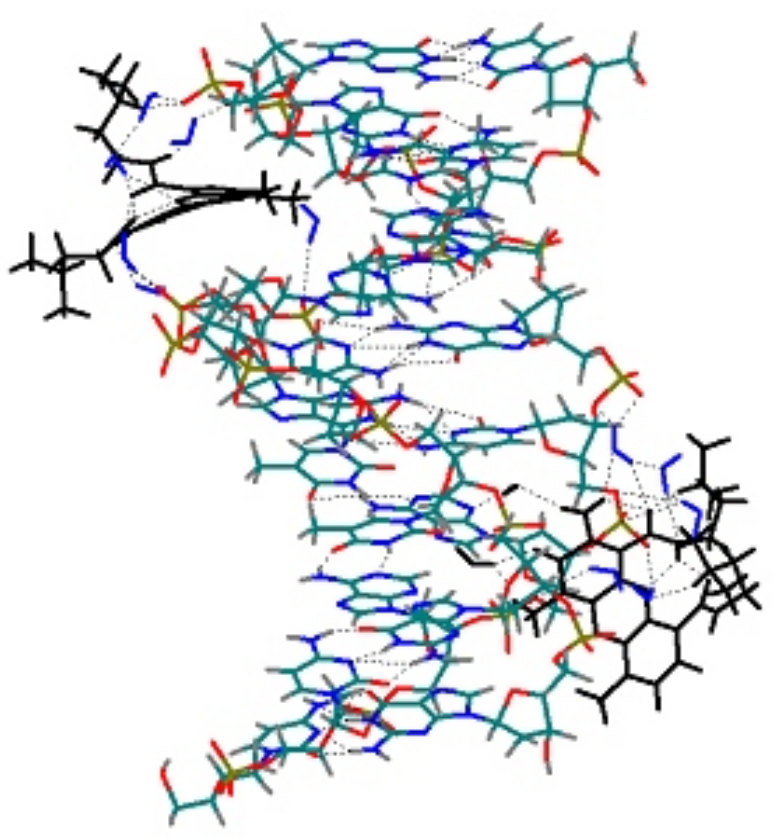

$A$

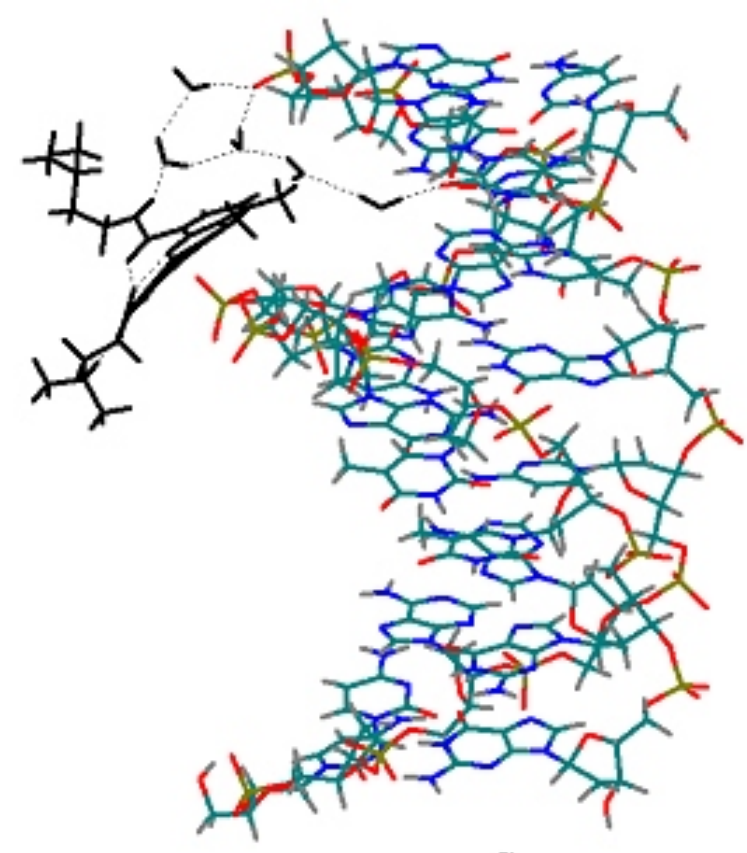

C

assessed on the basis of spectrophotometry data and as a result intercalation was shown to be noncoperative process and binding in the minor groove to be low-cooperative one $[7,8]$.

Let us consider the differences between different types of complexes. Binding of each of ActII molecules in

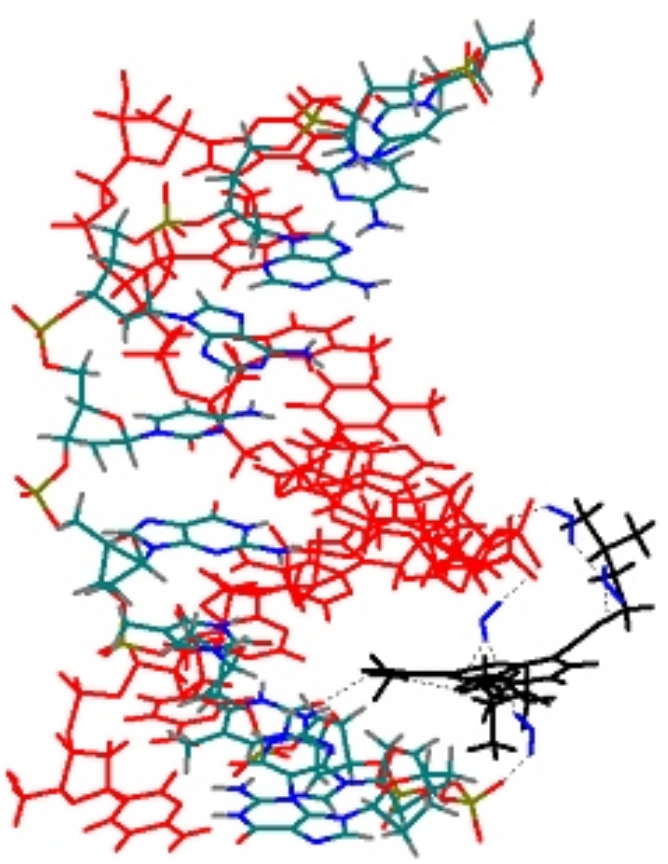

$B$

Fig.2 Binding ActII in the minor groove of DNA fragment (instantaneous configurations): $a$-both ligand molecules; $b, c$-for each ligand molecule. Water molecules occupy the bridge position between ligand molecules and DNA fragment. Hydrogen bonds are dot lined

minor groove of DNA fragment takes place with varying energy values of DNA-ligand fragment ( ${ }^{+} \mathrm{U}_{\text {DNA-ActII, }}$ Table). The difference is determined to be around $4 \mathrm{kcal} / \mathrm{mol}$. At simultaneous binding of both ActII molecules in the groove the interaction energy values of each of them with DNA fragment were shown to differ less. 

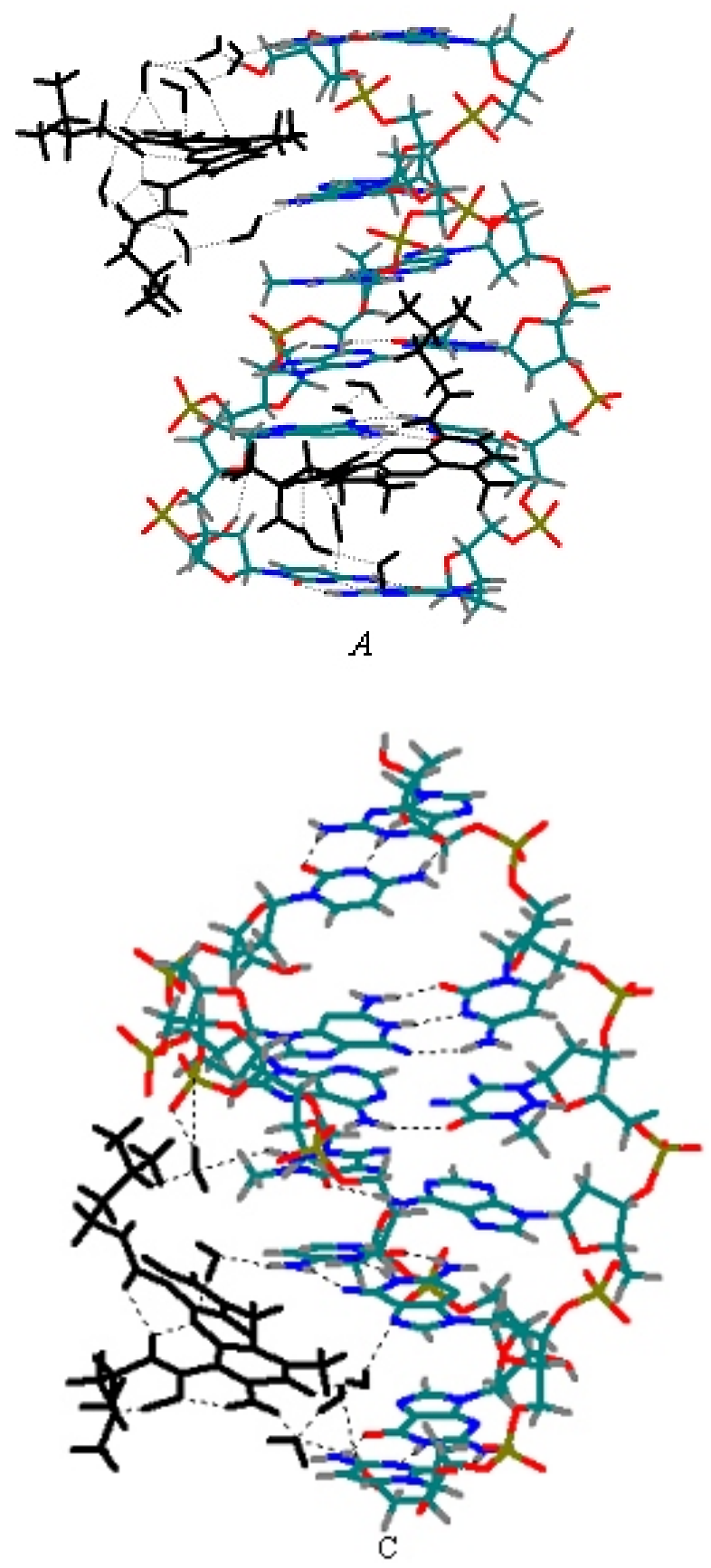

Analysis of instantaneous configurations of three complexes of this binding type allows determining H-bonds formed between amino group of ligand chromophore and $\mathrm{C}=\mathrm{O}$ thymine group (Fig.2, $b$ ). This fact may provide the explanation for the difference in the $U_{\text {DNA-ActII }}$ values, which is approximately equal to one

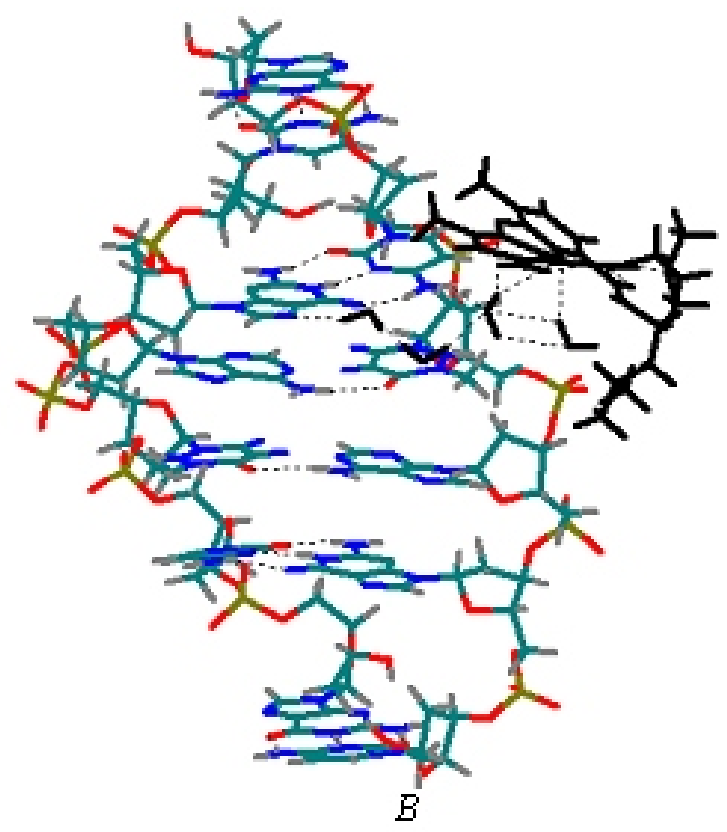

Fig.3 Intercalation of ActII into GC-sites of the DNA fragment (instantaneous configurations): $a$ - both ligand molecules; $b, c$ - for each ligand molecule. Water molecules occupy the bridge position between ligand molecules and DNA fragment. Hydrogen bonds are dot lined.

H-bond energy value. During the complex formation of H-bonds 2:1 between donor-acceptor groups of DNA fragment and ligand molecules has not been observed. A good correlation of ligand-DNA $\left({ }^{+} \mathrm{U}_{\text {DNA-ActII }}\right)$ interaction energy values is observed during the comparison of binding of one ActII molecule with the 
other DNA fragment - 5 -d(CGCGTTAACGCG) $)_{2}[6$, 8]. This value is $17.5 \mathrm{kcal} / \mathrm{mol}$ per base pair for 5 -d(CGCGTTAACGCG) $)_{2}$-ActII, which is close to the values of ${ }^{+} \mathrm{U}_{\text {DNA-ActII }}$ for different locations of ActII molecules at binding the fragment 5 -d(CCAACGTTGG), for both 1:1 and 2:1 complexes. Binding of the second ActII molecule in the minor groove has hardly any influence on the binding energy value of the second molecule (Table). The data presented allow supposing i) adequacy of the binding site size used in this work for modeling this type of the complex at ligand-DNA ratio 2:1 and ii) nonspecificity of ActII binding in the minor groove. Minimal size of the binding site for the complex with ActII molecule located in the minor groove was experimentally determined to be 3 b.p. [6, 7]. 2:1 model complex obtained using computer modeling, two ActII molecules were located in the minor groove 3-4 b.p. away along the helix axis (Fig.2,a).

Intercalation of one ActII molecule does not influence significantly the incorporation of the next molecule into the second GC-site of 5 -d(CGATCG) (Table, $\left.{ }^{+} \mathrm{U}_{\text {DNA-ActII }}\right)$, however, these values are $10 \mathrm{kcal} / \mathrm{mol}$ lower (absolute value) than the value of the interaction energy of one ActII molecule with GC-site of the bigger DNA fragment - $5-\mathrm{d}$ (GAAGCTTC) $2[6,8]$, which is $-30.2 \mathrm{kcal} / \mathrm{mol}$ per base pair (or $-241.2 \mathrm{kcal} / \mathrm{mol}$ per ligand molecule). Analysis of the instantaneous structures of the complexes revealed ActII not to form $\mathrm{H}$-bonds in the binding site, as well as no overlapping of the ActII chromophore plane with the base pair planes in the binding sites for all types of complexes studied. On the contrary, at the incorporation of one ActII molecule into the central GC-site of 5 -d(GAAGCTTC) ${ }_{2}$ a significant overlapping of aromatic systems of the ligands and the base pairs was observed and the formation of 2-3 H-bonds between donor-acceptor groups of ActII and DNA fragment was demonstrated $[6,8]$. These differences may be explained due to several reasons.

As it was mentioned above, the selected size of the binding site for ligands was too small which resulted in significant repulsion between positively charged ligand molecules and apparently, influenced their location in the binding sites. Besides, terminal effects have evident influence on the formation of such a structure as $2: 1$ complex binding sites, located on terminal ends of the DNA fragment, as well as nucleotide contents and the sequence of DNA fragment base pair. Therefore, the supposition on a higher specificity of the intercalation complex comparing to the binding ActII in the minor groove can be put forward.

The analysis of all complexes under investigation allows stating that their stability is determined by Van der Waals and electrostatic interactions. At the same time electrostatic interactions may make a destabilizing contribution. Electrostatic interactions between positively charged side ligand chains and negatively charged phosphate groups of the DNA fragments stabilize the complex, whereas the interaction between the same structural components of two ligands destabilize the complex. Water molecules contribute to the complex formation as well. The analysis of the interaction energies of the complexes and their components with water (interaction energy $U_{\text {wDNA }}, U_{\text {wActII }}$, $\left.U_{\text {ww/1 }}\right)$ as well as the structural characteristics of water environment of the complexes (number of water molecules which form $\mathrm{H}$-bonds with DNA fragments and/or ligands $N_{\mathrm{нb}}$, Table) show significant rearrangement of hydrate surrounding of the DNA fragments and ligands in the course of their binding. The table presents the similar data obtained at modeling the systems containing only DNA fragments or ligand molecule in water clusters ( 800 water molecules) and pure water cluster.

Water molecules which occupy the bridge position between donor-acceptor groups of ligand and DNA fragment were discovered in the binding sites of all types of complexes (Fig.2, 3). Water molecules occupy the bridge position between $\mathrm{C}=\mathrm{O}$ and $\mathrm{NH}_{2}$-groups of ActII chromophore and the groups of sugar-phosphate backbone and the base pairs, thymine $\mathrm{C}=\mathrm{O}$ group and adenine $\mathrm{N} 1$ atom of DNA molecule at binding of each of ActII molecules in the minor groove. Water molecules occupying the bridge position between sugar-phosphate backbone, $\mathrm{NH}_{2}$-group of cytosine and guanine $\mathrm{N} 7$ atom of DNA fragment and $\mathrm{C}=\mathrm{O}$ and amino groups of ActII chromophore were discovered during intercalation.

Conclusions. Low-energy structures of ActII complexes with DNA fragments which may be the most probable molecular models of two different types of 
complexes, i.e. ActII binding in the minor groove and intercalation ActII into GC with stehiometry 1:1 and 2:1 were obtained using the method of computer modeling. Energy stability of the complexes was shown to be determined by Van der Waals and electrostatic interactions as well as by the interactions with the solvent. While occupying the bridge position between donor-acceptor groups of DNA fragments and ligand molecules, water molecules contribute to additional stabilization of the complex formation. The sizes used in modeling are more adequate for the complex of ActII binding in the minor groove and are equal to 3-4 b.p. per ligand molecule. Apparently, the sizes for the intercalation complex have to be higher than those selected for modeling, i.e. higher than 4 b.p. per ligand molecule.

\section{А. В. Шестопалова}

Связывание производного актиноцина с фрагментами ДНК: моделирование методом Монте Карло

Резюме

Методом Монте Карло проведено компьютерное моделирование взаимодействия фрагментов ДНК и производного актиночина (ActII) с учетом водного окружения. Получены низкоэнергетические молекулярные структуры, соответствуюшие наиболее вероятным типам взаимодействия - связыванию АсtII в малом желобке и нтеркаляции ActII в GC-сайт с разной стехиометрией комплексов. Показано, что стабильность комплексов обусловлена Ван-дер-Ваальсовыми и электростатическими взаимодействиями, а также взаимодействием $c$ водным окружением, молекуль которого вносят дополнительную стабилизацию за счет образования мостиков между донорско-акиепторными группами фрагментов ДНК и лигандов. Определены возможные размеры мест связывания АсtII в малом желобке ДНК, составляющие 3 - 4 пары нуклеотидов (п. н.) на молекулу лиганда. При интеркалячии молекул ActII в GC-сайт размеры мест связывания очевидно больше 4 n. н. на молекулу лиганда. Полученные результаты согласуются с данными экспериментальных исследований.

Ключевые слова: фрагменты ДНК, производное актиноцина, комплексообразование, метод Монте Карло, размеры мест связывания, гидратаиия, межмолекулярные взаимодействия.

\section{REFERENCES:}

1.Круглова Е.Б. Сравнение эффектов связывания активных катионных красителей с ДНК в видимой и УФ областях // Вісн.Харьк.ун-ту, №525, Біофізичний вісник. - 2001. - вип.1(8). -С.27-33.

2. Круглова Е.Б., Больбух Т.В., Гладковская Н.А., Близнюк Ю.Н. Связывание антибиотиков актиноцинового ряда с матрицей полифосфата // Біополімери і клітина. - 2005. -21. -С.358-364.

3. Fox K R., Webster R., Phelps R.J., Fokt I., Priebe W. Sequence selective binding of bis-daunorubicin WP631 to DNA // Eur. J. Biochem. - 2004. -271 . - p. 3556-3566.

4.Chaires J.B, Curr.OpinDrug-DNA interactions // Curr.Opin.Struct.Biol. - 1998. - 8. - P. 314-320.
5. Круглова Е.Б., Малеев В.Я., Глибин Е.Н., Веселков А.Н. Физические механизмы взаимодействия производных актиноцина с ДНК. 6. Спектрофотометрическое исследование комплексов ДНК с производными актиноцина с разной длиной метиленовых цепей // Вісн.Харьк.ун-ту №560. - Біофізичний вісник. - 2002. - вип.1(10). - С.20-29.

6. Maleev V.Ya., Semenov M.A., Kruglova E.B. A spectroscopic and calorimetric study of DNA complexation with a new series of actinocin derivatives (ActII-ActV). В книге: Anti-cancer drug design: biological and biophysical aspects of synthetic phenoxazone derivatives. Editors: A.N.Veselkov, D.D.Davis; SEVNTU press, Sevastopol, 2002, P. 47-125.

7. Круглова Е.Б., Гладковская Н.А., Малеев В.Я. Использование метода спектрофотометрического анализа для вычисления термодинамических параметров связывания в системах актиноциновые производные - ДНК // Биофизика. - 2005. - 50. C. 253-264.

8. Maleev V.Ya., Semenov M.A., Kruglova E.B., .Bolbukh T.V, Gasan A.I., Bereznyak E.G. , Shestopalova A.V. Spectroscopic and calorimetric study of DNA interaction with a new series of actinocin derivatives // J. Mol. Struct. -2003. - 645. - P.145-158.

9. Анищенко Д.Б., Березняк Е.Г., Шестопалова А.В., Малеев В.Я. Изучение молекулярных механизмов взаимодействия кофеина и производных актиноцина с ДНК методом молекулярной динамики. II. Роль различных факторов при образовании комплекса ДНК-лиганд // Вісн.Харьк.ун-ту №593. -Біофізичний вісник. - 2003. - Вып.1 (12). - С. 13-19.

10. Miroshnychenko K.V., Shestopalova A.V. Flexible docking of DNA fragments and actinocin derivatives // J. Molecular Simulation. 2005. -31. - P. 567-574.

11. Danilov V.I., Zheltovsky N.V., Slyusarchuk O.N., Poltev V.I., Alderfer J.L. The study of the stability of Watson-Crick nucleic acid base pairs in water and dimethyl sulfoxide: computer simulation by the Monte Carlo method // J.Biomol.Struct.Dyn. - 1997. - 15. - P.69-80.

12. Alderfer J.L., Danilov V.I., Poltev V.I., Slyusarchuk O.N. A study of the hydration of deoxydinucleoside monophosphates containing thymine, uracil and its 5-halogen derivatives: Monte Carlo simulation // J.Biomol.Struct.Dyn. - 1999. - 16. - P.1107-1117.

13. Metropolis N., Rosenbluth A.W., Rosenbluth M.N., Teller A.N., Teller $E$. Equation of state calculations by fast computing machines // J.Chem.Phys. - 1953. - 21. - P.1087-1092.

14. Poltev V.I., Malenkov G.G. , Gonzalez E.J., Teplukhin A.V., Rein R., Shibata M., Miller J.H. Modeling DNA hydration: comparsion of calculated and experimental hydration properties of nucleic acid bases // J.Biomol. Struct.Dyn. - 1996. -13. - P.717-726.

15. Teplukhin A.V., Malenkov G.G., Poltev V.I. Monte Carlo simulation of DNA fragment hydration in the presence of alkaline cations using novel atom-atom potential functions // J.Biomol.Struct.Dyn. - 1998. -16. P.289-300.

16. Abraham F.F. Monte Carlo simulation of physical clusters of water molecules // J.Chem.Phys. - 1974. - 61. -P.1221-1225

17. Журкин В.Б., Полтев В.И., Флорентьев В.Л. Атом-атомные потенциальные функции для конформационных расчетов нуклеиновых кислот // Мол.биол. - 1980. - 14. - С.1116-1130.

18 Schmidt M. W., Baldridge K. K., Boatz J. A., Elbert S. T., Gordon M. S., Jensen J. H., Koseki S., Matsunaga N., Nguyen K. A., Su S. J., Windus T. L., Dupuis M., Montgomery J. A. GAMESS // J.Comput.Chem. - 1993. - 14. - P.1347-1363.

19. Granovsky Alex A. www http://classic.chem.msu.su/gran/gamess/index.html

20. Subramanian P.S., Beveridge D.L. A theoretical study of the aqueous hydration of canonical B d(CGCGAATTCGCG): Monte Carlo simulation and comparsion with crystallographic ordered water sites // J.Biomol.Struct.Dyn. - 1989. - 6. - P.1093-1122.

21. M.L.Kopka, D.S.Goodsell, I.Baikalov, K.Grzeskowiak, D.Cascio, R.E.Dickerson Crystal Structure of a Covalent DNA-Drug Adduct: Anthramycin Bound to C-C-A-A-C-G-T-T-G-G, and a Molecular 
Explanation of Specificity // Biochemistry. -1994. - 33. P.13593-13601.

22. Saminadin P., Dauntant A., Mondon M., D'estaintot B.L, Courseille $C$., Precigoux $G$. Release of the cyano moiety in the crystal structure of N-cyanomethyl-N-(2-methoxyethyl-daunomycin complexed with D(CGATCG) // Eur.J.Biochem. - 2000. - 267. - P.457-468
23. Rohs R., Bloch I., Sklenar H., Shakked Z. Molecular flexibility in ab inintio drug docking to DNA binding-site and binding-mode transitions in all-atom Monte Carlo simulations // Nucl.Acids Res. 2005. - 33. - P.7048-7057. 